\title{
The Road to East African Integration
}

\author{
Wanyama Masinde and Christopher Otieno Omolo
}

\subsection{Introduction: African Regionalism in a Global Perspective}

In recent times, the world has witnessed on the one hand, a trend towards globalization, which has resulted in a "more interconnected world economy and world society" characterized by fewer and less significant trade borders, and is associated with the decline of the nation-state, and on the other, a trend towards regionalization and cooperation between states or groups of states. ${ }^{1}$ Gamble, citing Kenichi Ohmae, observes that economic activity in the contemporary global economy no longer coincides with traditional political and cultural fault lines, so much so that the nation-state is fast being rendered irrelevant, at least as a unit of analysis. ${ }^{2}$ The post-Cold War era has particularly featured a resurgence of regionalism across the globe, with both old regional blocs being revived and new ones formed. Many reasons have been advanced to account for the revival of regionalism, including, the end of the Cold War and "the erosion of the Cold War alliance systems", the unreliability of the General Agreement on Tariffs and Trade (GATT), and the many economic and democratic developments in the developing world. ${ }^{3}$ The success story of the European regionalization experiment has also been cited as a factor that has inspired the recent wave of regionalism. ${ }^{4}$

1 Eiassen, K.A., \& Monsen, B. (2001). Comparison of European and Southeast Asian Integration. In M. Telò, European Union and New Regionalism: Regional Actors and Global Governance in a Post- Hegemonic Era (pp. 111-135). Burlington: Ashgate, at 113; Gamble, A. (2001). Regional Blocs, World Order and the New Medievalism. In M. Telò, European Union and New Regionalism: Regional Actors and Global Governance in a Post-Hegemonic Era (pp. 21-39). Burlington: Ashgate. at 21.

2 Gamble, supra note 1, at 23.

3 Eiassen \& Monsen, supra note 1 , at 113.

4 El-Affendi, A. (2009). The Perils of Regionalism: Regional Integration as a Source of Instability in the Horn of Africa? JOURNAL OF INTERVENTION AND STATEBUILDING, 3 (1), at 1. See further on the example of EU integration EU Chapter 1 detailing the road to European integration. 
1.2

The Post-Hegemonic Era and the Search for a New Multilateral Equilibrium

Most analysts have generally cited the "post-hegemonic condition" of the post-Cold War international system as constituting the congenial background for the resurgence of regionalism. The post-hegemonic condition, to cite Padoan, is a "situation in which no single country can provide unilaterally, the public goods required for the operation of the (international) system". ${ }^{5}$ The post-hegemonic world is also said to be a world in "a state of institutional disequilibrium", that is, a state in which there is "an excess demand for international public goods" as a result of the combination of, a decrease in supply because of the erosion of the power of the hegemon, and an increase in demand, because of globalization" ${ }^{6}$ This condition is ascribed to the decline of the United States as a hegemon in the last few decades. The United States had emerged as a new hegemon after the Second World War, and had led the successful reconstruction of the global political economy in the 1950s and 196os, guaranteeing "the conditions for a safe liberal world order". ${ }^{7}$ However, the economic turbulences of the 1970s and 1980 s led to "the erosion of the economic supremacy of the United States" and resulted in the decline of its hegemonic power and ability to supply public goods, thereby rendering the world susceptible to "mercantilists and protectionist policies" by nation-states. ${ }^{8}$

Regionalism, against this view, is perceived, not just as the result of the "convergence of trade and investment activities" by different groups of nation-states, but, as "a policy pursued as a response to the failure of the post-hegemonic world in providing international goods". ${ }^{9}$ Regionalism has therefore been pursued as an attempt to provide a sort of new multilateral equilibrium in the absence of a hegemonic power. Proponents argue that regionalism can contribute to global governance by providing solutions to the demand for public goods, and conditions for new multilateralism. Telò, for instance, points out that regionalism is a good precondition for multilateralism since interaction

5 Padoan, P.C. (2001). Political Economy of New Regionalism and World Governance. In MarioTelò, European Union and New Regionalism: Regional Actors and Global Governance in a Post-hegemonic Era (pp. 39-59) Burlington: Ashgate, at 40.

6 Padoan, supra note 5 .

7 Gamble, supra note 1, at 26.

8 Gamble, supra note 1, at 26.

9 Padoan, supra note 5. 
between states and international organizations is easier at the regional level. ${ }^{10}$ $\mathrm{He}$ also notes that regionalism enhances stability in international regimes because it implies "issue linkages" for instance, between economic, security, monetary and trade issues, which in turn leads to exchange of information, and provides security.11

\subsection{New Regionalism and Globalization}

An important subject within the discourse on regionalism has been its relationship with the nation-state and with globalization. There have been debates about the roles played by the nation-state and international economics and world politics in the emergence of new regionalism. Telò has, for instance, argued that both factors are responsible for the development of new regionalism. He contrasts between domestic or internal factors, and the systemic or exogenous economic and political factors, which he argues, constitute the causes of the recent wave of regionalism. ${ }^{12}$ By domestic factors he means, the combination of the desire of nation-states to rescue their sovereignty and maintain or recover international bargaining power; the private interest of industries lobbying and networking on a regional basis; the "internal functional spillover" resulting from regional cooperation agreements; and the desire of developing countries to cope with global competition. ${ }^{13}$

The major systemic factor in the development of regionalism, Telò explains, has been globalization, understood as the combination of the international forces, political actors and multinational organizations shaping the "relations and hierarchies between states, economic interests and regions of the world". 14 Telò sees regionalism as the nation-state's response to a two-pronged threat which globalization poses to its existence. On the one hand, he sees regionalism-regional trade liberalization and cooperation arrangements - as a measure that enables nation-states and companies to "cope with the risks and opportunities of the global market and to absorb new multilateral rules". ${ }^{15}$ On the other hand, he perceives regionalism as a

\footnotetext{
10 Telò, M. (2001). European Union and New Regionalism: Regional Actors and Global Governance in a Post-hegemonic Era. Burlington: Ashgate, at 13.

11 Telò, supra note 10.

12 Telò, supra note 10 , at 4.

13 Telò, supra note 10 , at 4.

14 Telò, supra note 10, at 4.

15 Telò, supra note 10, at 6.
} 
response by nation-states to the threat of financial, technological and market globalization to the traditional "territorial state power". ${ }^{16}$ According to this perspective, regionalism rescues national authority by enabling states to pool their authority at a regional level, in the face of the weakening or decline of national sovereignty. Telò observes that traditional state powersovereignty - has been under threat, not only from technological and market globalization, but also from domestic "social factors, political pressures, and democratic authority". ${ }^{17}$ Hence, regionalism does not only rescue the nation-state from global political and economic forces, but, by creating a new supranational framework within which different actors express themselves, limits the "fragmenting and disintegrating impact of subnational regionalism, ethnic fundamentalism and the proliferation of movements (agitating) for self-determination". 18

Regionalism thus helps countries cope with traditional deficiencies of the nation-state, and to respond accordingly to a globalized economy. The nexus of regionalism with globalization is a subject much discussed in the literature of regionalism, and thus demands more than a cursory treatment here. As already noted, the resurgence of regionalism has been closely associated with the rise of globalization, which has been an important feature of the world economy since the 1980 s. There is a consensus that there has been an evolution in the functioning of the world economy and in the operations of multinational corporations, driven by rapid technological advances, increased volumes and increased liberalization of trade, and unimpeded financial flows. ${ }^{19}$ Whereas this evolution has brought massive benefits in terms of increased volumes of trade, and increased investment and growth, it has also brought with it challenges for governments. Globalization and liberalization have, for instance, been associated with the weakening of the government's control over their national economies, and in fact exposed domestic economies to external shocks. ${ }^{20}$ Telò, rephrasing Gamble, has noted that "globalizers" speak of "hyper-globalization" as constituting the threat to which regionalism seeks to

\footnotetext{
16 Telò, supra note 10, at 7.

17 Telò, supra note 10 , at 7 .

18 Telò, supra note 10 , at 7 .

19 Eiassen \& Monsen, supra note 1, at 113.

20 Eiassen \& Monsen, supra note 1, at 113; Jenkins, C., \& Thomas, L. (2001). African Regionalism and the SADC. In M. Telò, European Union and New Regionalism: Regional Actors and Global Governance in a Post-hegemonic Era (pp. 153-177). Burlington: Ashgate, at 159 .
} 
respond. By hyper-globalization he refers to "a new-liberal" vision of the global economy as "cosmopolitan"; characterized by a "fast convergence of national economies" and an increasing autonomy of transnational companies, global financial markets, and private and public networks. ${ }^{21}$ "Hyper-globalization" exacerbates the crisis of territorial sovereignty, and in the extreme, renders the state all together, superfluous. Governments react to globalization by setting up regional blocs to enhance their competitiveness in the new global framework. In fact, Telò observes, regionalism is not only the state's alternative to globalization, but also constitutes the state's gateway to the global economy. ${ }^{22}$ This point is best illustrated by Vasconcelos in his discussion of MERCOSUR. He states that MERCOSUR is a project generated by globalization, and born from the awareness of Member States like Brazil and Argentina of the difficulties the nation-states, with their sovereignty deprived of potency, face "on their own to benefit from globalization and to meet the economic and security challenges it brings". ${ }^{23}$ Jenkins and Thomas reiterate this point in regard to African regionalism, arguing that regionalism should be perceived not just as an alternative to trade liberalization but as a step in "a process of greater integration into international markets". ${ }^{24}$ Referring to the South African Development Community (SADC), they state that regional integration, by creating larger markets, could enable SADC to compete in the global economy. ${ }^{25}$

Regionalism and globalization are said to be complementary, even if they bear conflicting tendencies. Gamble notes, quite rightly, that both globalization and regionalism comprise complex processes of social change with unique patterns of social interaction of actors, which occur independently of the state. ${ }^{26}$ This is reiterated by Telò who observes that regionalism and globalization are two components of the same "historical process of strengthening interdependence and weakening the state's barriers to free trade.....27

\footnotetext{
21 Telò, supra note 10, at 9.

22 Telò, supra note 10, at 9.

23 Vasconcelos, Á. d. (2001). European Union and Mercosur. In M. Telò, European Union and New Regionalism: Regional Actors and Global Governance in a Post-hegemonic Era (pp. 135-153). Burlington: Ashgate, at 137.

24 Jenkins, supra note 20 , at 137.

25 Jenkins, supra note 20, at 137.

26 Gamble, supra note 1, at 27.

27 Telò, supra note 10 , at 1.
} 
Another feature of new regionalism has been its association with the European Union (EU). There is a general consensus amongst theorists of regional integration that the success story of EU integration has provided both the inspiration and the normative model for the new wave of regionalism throughout the world. It is no surprise therefore that much of the analysis of the phenomenon of new regionalism has featured, almost invariably, a comparative study of the EU and other regional organizations. Telò observes that specialists have approached regionalism from the perspective of the $\mathrm{EU}$, focusing on the comparison of regional arrangements with the $\mathrm{EU}$, and on the evolution of the $\mathrm{EU}$ as "both a workshop of institutional innovation and an international entity" in the post-Cold War era. ${ }^{28}$ The present work of course contributes to this larger comparative exercise, even if hoping to avoid some of its traps.

The EU has quite explicitly, in its external relations, contributed to the development of regional cooperation in many parts of the world. The setting up of inter-regional cooperation is in fact seen as an important element in the EU's self-consciousness as a new global actor. As Vasconcelos has noted, the global actorship of the EU has consisted in building a new form of multilateralism based on "areas of regional integration and on the experience of supranational regulation of the relations between states", that is, it seeks to turn the international system into "a 'community' on the basis of the success of its own model, which is then extrapolated into the wider world". ${ }^{29}$ For this reason, the EU has sought to establish partnerships with regional organizations throughout the world, and now supports the development of regionalism in Asia, Latin America, and Africa. Many regional blocs have been created or re-invented to emulate, or in reaction to, the success story of the $\mathrm{E} U$.

The extrapolation of the EU model has of course not been without challenges. The EU model's incompatibility with some regions of the world has been reported. El-Affendi, for instance, cites the incompatibility of this model of integration with the Third World economies as a major impediment to the growth of regionalism in Africa. ${ }^{30} \mathrm{He}$ argues that the success of the E $\mathrm{U}$ model depends on the emergence of strong and diversified economies, "and presupposes economic complementarity and a strong political commitment" to overcome asymmetrical benefits and costs of integration. ${ }^{31}$ However, it suffices

\footnotetext{
28 Telò, supra note 10 , at 3.

29 Vasconcelos, supra note 23, at 150.

$30 \quad$ El-Affendi, supra note 4 , at 5 .

31 El-Affendi, supra note 4 , at 5.
} 
to state, as Telò aptly does, that the future of new regionalism is "intrinsically linked to the evolving EU".32 Although one must remain acutely aware of the risks of too direct or simplistic a comparison, the $\mathrm{EU}$ therefore remains the primary comparative model.

\subsection{Regionalism in Africa: A Historical Perspective}

The fire of new regionalism enkindled in the heart of Europe has also been raging across the continent of Africa. Indeed, regionalism itself is not a new phenomenon in Africa. Some of the world's oldest custom unions are found in Africa, a legacy of colonialism. Whereas we associate the African regional trade integration initiatives since the 1960s with what Telò has called the "economic regionalism" (which emerged alongside us-centered multilateralism of the same period), the actual urge for the unification of the African continent predates the African Independence. ${ }^{33}$

There has always existed in the collective consciousness of Africa, at least in Sub-Saharan Africa, a view that the geographical fault lines that created different African states divided a previously united people. Thus, since the Independence, there have been persistent calls for African Unity. Even if, in the subsequent decades following the Independence, the rather idealistic dream of a politically united Africa, tempered by the complex realities of nation-building, has given way to more modest forms of integration, Africa has remained steadfast in its belief that its welfare is predicated on the unity of the continent.

As Olivier has noted, African regionalism in the post-colonial era has evolved chronologically, in episodes, beginning with the anti-colonial fervor of the immediate post-Independence period which featured a clamor for unification under such slogans as "African Unity", "African Fraternity" and "PanAfricanism". ${ }^{34}$ This episode envisaged a unification process that would lead to the creation of a single African political state-the United States of Africa. Ironically, the institutional embodiment of this dream-the Organization for African Unity (OAU) - would have as one of its main objectives, the defence of the sovereignty of the nation-state inherited from colonialism, a principle that is credited with undermining the integration projects in Africa.

\footnotetext{
32 Telò, supra note 10, at 90.

33 Telò, supra note 10, at 13 .

34 Olivier, G. (n.d.). Regional Integration in Africa: A Political Perspective. Unpublished Manuscript, $1-18$, at 8.
} 
Olivier has cited this paradox, noting that despite all the rhetoric about African Unity at the formation of the OAU, the "state-centric (confederal) Westphalian model of sovereignty was accepted and institutionalized as the ruling paradigm and political lode star". ${ }^{35}$ Hence, whereas one would expect that because of a sense of identity that "manifests so prominently" in SubSaharan Africa, it would be easier to achieve African Unity, than in a more heterogeneous region like Europe, this would never be the case. ${ }^{36}$ African Unity would remain largely elusive in the decades after Independence. The first attempts at regional integration were hamstrung by several factors, including, "lack of clear leadership and the iron law of impenetrable national sovereignty", and the failure to move beyond minimalist-intergovernmental cooperation. ${ }^{37}$ The efforts at integration were further compounded by the subversive post-colonial leadership "driven by the expediency and power-political considerations", and the twin burdens of nation-building and consolidation of national identities. ${ }^{38}$

The second episode featured a shift from the idealism of the Pan-Africanist project to a more modest approach to regional integration, focusing on the "sub-regional economic domain of market-driven intra-state, or extra-territorial cooperation". ${ }^{39}$ In the 1960 s and 1970s, many African states were tempted into forming regional economic blocs. These attempts basically involved pooling some competencies of domestic regulation and policy at a supranational level. Many regional blocs sprouted across the continent within this framework for example, the SADC, the original East African Community (EAC) and the Economic Community of West African States (EcowAs). However, this form of regionalism was impeded, again, by the lack of will on the part of the states to cede any power to any supranational body.

A third phase in the evolution of African integration happened at the instigation of a combination of systemic factors. In the 1980s, the United Nations through its Economic Commission for Africa (ECA) supported the Lagos Plan of Action (LPA) and the Full Act of Lagos (FAL), initiated by the OAU, as part of its efforts to revitalize the African economy in the wake of the failure of the post-colonial economic strategies of the preceding decades. ${ }^{40}$ The plans proposed a new Pan-African approach to Africa's economic problems

\footnotetext{
35 Olivier, supra note 34 , at 6.

36 Olivier, supra note 34 , at 6.

37 Olivier, supra note 34 , at 1.

38 Olivier, supra note 34 , at 6.

39 Olivier, supra note 34 , at 8.

$40 \quad$ Olivier, supra note 34, at 9; El-Affendi, supra note 4, at 3 .
} 
that included the establishment/revitalization of three Regional Economic Communities (RECs) as a step towards continental integration. They included the revitalization of the already existing, EcowAS in West Africa, the establishment of the Preferential Trade Area (PTA) in 1981 for Eastern and Southern African states, and the Economic Community for Central African States (ECCAS) in $1983 .{ }^{41}$ Olivier remarks that the LPA was indeed an important phase in the evolution of regional integration for re-introducing such pan-Africanist themes like "African solidarity, collective self-reliance and self-sufficiency, economic progress on self-sustaining socio-economic development, reducing its dependence vulnerability vis-à-vis 'external nations'". 42 The LPA underscored the importance of regionalism for African economic progress, expressly urging that "efforts towards African economic integration" be pursued with "renewed determination" so as to create a continental framework for cooperation. ${ }^{43}$

The Abuja Treaty of 1991 marked the beginning of another phase in the evolution of African integration. The Abuja Treaty was an improvement on the LPA. While indicting the African leadership with failure to confront Africa's economic problem, the Abuja Treaty reiterated the importance of regional integration, and in fact set the timeline for full continental economic integration at $2025 .{ }^{44}$ The Abuja Treaty recommended the rationalization of RECs to address the problem of multiple membership African states. ${ }^{45}$ It envisaged the ultimate continental integration which would culminate in the African Economic Community (AEC) which would be achieved progressively, beginning with the revamping of existing, or the development of new RECs, as building blocks. ${ }^{46}$ The immediate post-Abuja Treaty era saw the revitalization of main regional economic blocks. Within its framework, the PTA was replaced by the Common Market for Eastern and Southern Africa (COMESA) in $1993 .{ }^{47}$

Perhaps the most important phase in African integration was set off by the Sirte summit of 2001 which replaced the OAU with the African Union $\mathrm{AU})$. Olivier has noted that the launching of the AU marked the beginning of the "ultimate episode in African integration". ${ }^{48}$ The AU, Olivier observes,

\footnotetext{
41 El-Affendi, supra note 4, at 3.

42 Olivier, supra note 34 , at 10.

43 Olivier, supra note 34 , at 10.

44 El-Affendi, supra note 4, at 3.

45 African Development Bank. (2016). Eastern African Regional Integration Strategy Paper (2011-2015).REGIONAL DEPARTMENTS -EAST (orEA/orEB). African Development Bank, at 1.

46 African Development Bank, supra note 45.

47 El-Affendi, supra note 4, at 3.

48 Olivier, supra note 34 , at 12.
} 
essentially perpetuates the OAU paradigm of integration, emphasizing the OAU's foundational principles of "unity, solidarity, cohesion and co-operation". 49 However, whereas it generally upholds the Westphalian nation-state concept that has dominated the past integration projects, it adopts a weaker form of sovereignty, providing for intervention in the member states, "in respect of 'grave circumstances' or if requested by member states to restore peace and security". ${ }^{50}$ In the words of Olivier, the AU waters down the old African dictum of "non-interference: to "non-indifference". 51

The AU also has the quality of being a remote replica of the EU. By its structure and objectives, it exemplifies the type of regionalism that belongs to the species of new regionalism. Olivier has observed that even though the $\mathrm{EU}$ and $\mathrm{AU}$ are sui generis organizations in different ways, they nevertheless share some structural and even foundational philosophical underpinnings. ${ }^{52}$ He identifies convergence in the intellectual underpinnings of integration, and the role perceptions of both organizations. He observes, for instance, that both the $\mathrm{AU}$ and $\mathrm{EU}$ emerged against backgrounds of nation-state failures: just as the "idea of Europe" evolved as a "remedy against nationalistic wars", the "idea of Africa" has similarly been inspired by anti-colonial sentiments, and the past failures of African nation-states. ${ }^{53}$ Moreover, he adds, just as the EU has evolved out of the acknowledgement by post-war Europe that unity would be essential for survival in the bi-polar Cold War world dominated by the United States and the Soviet-Union, African integration has also been inspired by the appreciation of the need for unity in the face of the Cold War and Western economic dominance in the post-colonial era. ${ }^{54}$

The AU also shares the structural framework of the EU, having adopted such institutions as the Commission, the Council, and the Parliament, even if each of these are endowed with less power compared to those of the EU. Of course, for obvious reasons, many differences abound between the two organizations. Perhaps most noteworthy is the fact, as Vines has observed, that the AU came into existence fully formed and therefore did not have to confront

\footnotetext{
49 Olivier, supra note 34 , at 12.

$50 \quad$ Olivier, supra note 34 , at 12.

$5^{1}$ Olivier, supra note 34 , at 12.

52 Olivier, supra note 34 , at 1.

53 Olivier, supra note 34 , at 1.

54 Olivier, supra note 34 , at 1.
} 
some of the challenges that the EU faced in its evolution. ${ }^{55}$ This also means that it did not have any accession criteria and there was no threshold of democratic or economic behaviour that a state needed to attain before admission. Whereas the EU integration has evolved in a linear succession, from simple preferential trade area, to free trade area, through customs union, common market, economic union, towards, ultimately, political union, the AU has adopted a more "top-down" approach to integration, that began with the mega unification projects embodied in OAU/AU, and then moving to the RECs. ${ }^{56}$ Still, the EU integration, because it has been a success, provides the best model for the kind of regionalism to which Africa aspires.

The AU and the RECs initiated within its framework, have exemplified new regionalism both in origins and objectives. There is a considerable discontinuity between the pre-Sirte summit regionalism and regionalism after the summit. Indeed, after the Abuja Treaty of 1991, regionalism in Africa has been mainly driven by the fear of marginalization of the continent in the new world order characterized by regionalism on the one hand, and globalization on the other. As observed above, the new wave of African regional integration has also been instigated by systemic factors such the international community (the United Nations), and the European Union.

However, as Olivier notes, regional integration in Africa still constitutes at best, a "work in progress" en route to deeper regional integration, and compared to the EU which it holds as a model, it is still in its "rudimentary stages".57 The political union, which would feature deeper institutional integration, is yet to be achieved, and is conditioned, as rightly reported by Telò, by the "heterogeneity and pre-democratic" nature of the nation-states. ${ }^{58}$ Many factors, such as the weight of the colonial past, "the legacy of the Cold War, the cultural, religious, and linguistic diversity, the unique relation between state and society," and together with the perennial problems of under development, the lack of harmonization between national economies, and indeed the ever present political tensions between and within Member States, have conspired to slow down the process.

\footnotetext{
55 Vines, A. (2013). A Decade of African Peace and Security Architecture. International Affairs, $89(1), 89-1-9$, at 95 .

56 Olivier, supra note 34 , at 15 .

57 Olivier, supra note 34 , at 5 .

58 Telò, supra note 10 , at 77 .
} 
1.6 African Regionalism: A Factor in the Decline of the Post-Colonial State?

The debate on the relationship between regional integration and the nationstate in Africa is a prominent feature of the discourse on African regionalism, just as it has featured prominently in the discourse on new regionalism in general. As already observed, the place of the state within the framework of regional integration has constituted an essential fault line in the theoretical debates about new regionalism. In Africa, the strong hold of the Westphalian paradigm of state sovereignty-a legacy of colonialism-on politics and economics, has limited the efforts for regional integration to minimalist intergovernmentalism.

The assertion of a strong form of state sovereignty has repeatedly been cited as one of the contributing factors to the failure of regional integration in Africa. There is no doubt that Africa recognizes the importance of regionalism for political and economic progress, but it seems African governments wish this were achievable without having to cede their authority, or shift their loyalties to some continental federal or supra-national institution which they cannot control; or rather that regionalism should complement rather than supplant their national projects. In fact, as Oyugi explains, the governments have preferred to view regionalism as an instrument that supplements or enhances or protects the role of the nation-state. ${ }^{59}$ Proponents of this view have also held that regionalism rescues rather than weakens the nation-state in Africa, and provides a gateway for the continent into the global political economy.

Africa's experiment with the Westphalian state system has been notably characterized by dismal failure. Anadi has observed that the independent African states were, in the first place, never "really negotiated states"; they were imposed by colonialism against the consent of the nationalities and thus, always struggled for legitimacy. ${ }^{60}$ Lacking legitimacy, the states have relied heavily on force to sustain power, and consequently could not "sufficiently harness the advantages of 'political plurality and ethnic diversity' in nation building". 61 With attention and resources diverted towards strengthening

59 Oyugi, E. (2009). East African Community—-the Third Round: A People, Market or Statedriven Regionalisation project? EAC 1oth Anniversary Symposium: Role of Non-State Actors in Deepening EAC Integration (p. 9). Arusha: East African Community, at 2.

6o Anadi, S.K. (2005).REGIONAL INTEGRATION IN AFRICA:The case of ECOWAS. Zürich: Zürich University, at 19.

61 Anadi, supra note 6o. 
legitimacy, the states therefore have never been able to pay due attention to the development of sustainable socio-economic and political institutions. The weaknesses have also rendered the African state vulnerable to the forces of globalization. In the post-independent era, the African state has witnessed several conflicts, some of which have in fact threatened its very existence. ${ }^{62}$ The case of the African state has typified the inability of the nation-state to singularly provide "public goods". Like every part of the world, regionalism has presented Africa with an opportunity to address the failures of the nation-state and to respond to the threat of globalization. It is within this context that the East African Community, to which we now turn, came into existence.

\subsection{Regionalization in the East African Community}

An African Development Bank (AfDB) Strategy Paper on Eastern African Regional Integration reports that the Eastern African region has the largest number of RECs and intergovernmental bodies in Africa, with each of the $12^{63}$ countries in the region possessing membership of six of the eight RECs recognized by the AU. ${ }^{64}$ Six of the twelve Eastern African countries-Burundi, Kenya, Rwanda, Tanzania, Republic of South Sudan and Uganda, constitute a regional bloc known as the East African Community (EAC). The EAC defines itself as a regional intergovernmental organization that aims at "widening and deepening co-operation among member states in, among others, political, economic and social fields for their mutual benefit".65 The organization has established a Customs Union (2005) and a Common Market (2010), and is in the process of establishing a Monetary Union. Its ultimate objective is to establish a complete political Union - a "Political Federation of the East African States".66

\footnotetext{
62 Anadi, supra note 60.

63 See Fig. 1, East Africa' (African Development Bank Website) <http://www.afdb.org/en/ countries/east-africa/> accessed 31 July 2016.

64 African Development Bank, supra note 45, at v.

65 http://www.eac.int/faqs, EAC. (2013). Home: About EAC. Retrieved April 9, 2016, from An East African Community Website: http://www.eac.int/index.php?option=com_content\& view $=$ article\&id $=1$ : welcome-to- eac\&catid $=34$ :body-text-area\&Itemid $=53$. 


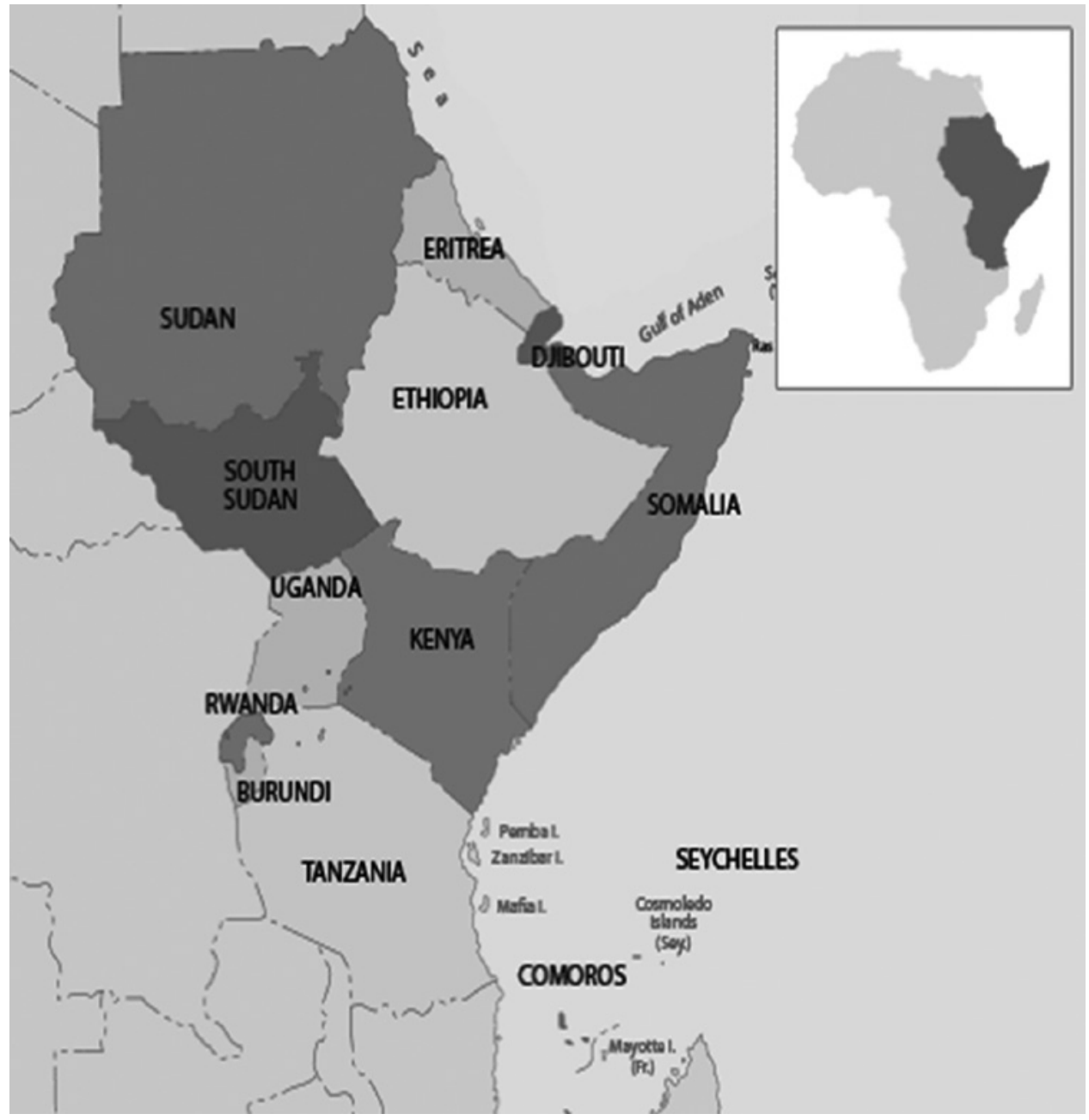

FIGURE 1.1 Map of Eastern Africa. ${ }^{67}$ SOURCE: AFRICAN DEVELOPMENT BANK WEBSITE (2016).

\subsection{The Defunct EAC}

The EAC is, like the AU, a reincarnation of a defunct predecessor. The history of regional integration in East Africa can be traced to the late 19th century, in the very early days of colonialism in the region. As noted in the preamble

67 'East Africa' (African Development Bank Website) <http://www.afdb.org/en/countries/ east-africa/> accessed 31 July 2016. 
to the Treaty for the Establishment of the East African Community, the formal and social integration in the region can be traced to the construction of the Kenya-Uganda Railways from 1897-1901, the establishment of the Customs Collection Center for Uganda in Mombasa in 1900, and the East African Currency Board and the Postal Union, in $1905 .{ }^{68}$ These were later followed by the establishment of the Court of Appeal for East Africa in 1909, the Customs Union for Uganda, Tanganyika and Kenya, then under British administration, in 1919, among other regional initiatives. ${ }^{69}$

Perhaps the most significant milestone in the process of regional integration at this stage was the formation of the East African High Commission in 1948 , to strengthen economic links between the three countries. ${ }^{70}$ The Commission established a unified income tax for the three countries. It was succeeded by the East African Common Services Organization, which was established in 1961 to coordinate such regional service organizations as the East African Posts and Telecommunications, the East African Railways and Harbors, the East African Airways, the East African Air Aviation Services and the East African Development Bank. ${ }^{71}$ In 1967 , a treaty—The Treaty for the East African Cooperation - was signed by three East African nations-Kenya, Tanzania and Uganda - establishing the East African Community, and succeeding the East African Common Services Organization. ${ }^{72}$ Under the Treaty, the three nations agreed to cooperate in a wide array of economic and social issues. The Community fostered cooperation in many areas within the region, and was considered at the time a model of regional integration and development. The integration achieved under the Community was so deep that it was, as Kiraso has observed, "in all but name, a federal government". ${ }^{73}$ However, in 1977, barely a decade after it came into existence, the EAC collapsed. Several reasons have been advanced to explain why the Community collapsed. Shivji explains it rather aptly:

68 EAC. (2010). Home: Treaty Establishing the East African Community. Retrieved April 08, 2016, from East African Community Website: http://www.eac.int/treaty/index .php?option $=$ com_content $\&$ view $=$ article \&id $=75 \&$ Itemid $=156$, at 3 .

69 EAC, supra note 68 , at 4 .

70 Kiraso, B.B. (2009). EAC Integration-Enabling Peace and Security Architecture. EAC Peace and Security Conference (p. 18). Kampala: East African Community, at 2; Reith, S., \& Boltz, M. (2011). The East African Community Integration: Between Aspiration and Reality. Ambition for and Reality of the East African Community in a Globalized World (pp. 91-107). Dar es Salaam: Konrad Adenauer Stiftung, at 92.

71 Kiraso, supra note 70.

72 EAC, supra note 68, at 5 .

73 Kiraso, supra note 70. 
The East African Community formed in 1967, which attempted to address one of the deep-rooted scourges of colonialism, uneven development, also fell victim to the forces of compradorialism and imperialism. It is not necessary to go into details. Suffice it to say that the limited economic unity could not be sustained in absence of a durable political framework. And a durable political framework could not be developed in absence of political unity. ${ }^{74}$

The Treaty that would re-establish the Community more than two decades later points to "lack of strong political will, lack of strong participation of the private sector and civil society in the cooperation activities, the continued disproportionate sharing of benefits of the Community among Partner States due to the differences in their levels of development and lack of adequate policies to address the situation" as the contributing factors to the collapse of the Community. ${ }^{75}$

Many analysts have cited the strong intergovernmental (interstate) structure of the Community, and the ideological differences between the leaders of the Member States as the main reasons for the collapse. For example, in the 1970s, Tanzania was drifting towards Socialism, while Kenya adopted a Capitalist system and this ideological incongruence played out in the Community. Mugomba has pointed out also that beyond ideology, regional conflict, and external systemic penetration, the East African Community integration was also subverted by such factors as "the growing 'radicalization' of regional politics, including the proliferation of Marxist-oriented regimes in Eastern and Southern Africa; Kenya's contribution to the 'development of underdevelopment' within the Community and the Common Market, as well as the increasingly conservative, authoritarian, and defensive position of Kenyatta's regime both at home and in the region". ${ }^{76}$ Furthermore, the collapse of the Community is also blamed on governance challenges such as the absence of mechanisms to address corruption, non-respect for rule of law, and impunity. ${ }^{77}$

74 Shivji, I.G. (2009). Pan-Africanism and the Challenge of East African Integration. EAC 1oth Anniversary Symposium (13-14 November, 2009): Pan-Africanism and the Challenge of East African Integration (p. 11). Arusha: East African Community, at 6.

75 EAC, supra note 68.

76 Mugomba, A.T. (1978). Regional Organizations and African Underdevelopment: the Collapse of the East African Community. The Journal of Modern African Studies, 16 (2), The Journal of Modern African Studies, at 270.

77 Kiraso, supra note 70, at 1. 
The collapse of the Community led to the dismemberment of its jointlyoperated services, with each Member State assuming direct control over regional services within its territorial boundaries. Regional projects—railways, ports, harbors, postal services and airlines - were all now managed separately. However, even with the collapse of the Community, the East African states still acknowledged the advantages of integration for the region and it was always hoped that the Community would be revived at some later date. Therefore, the Mediation Agreement of 1984, which set the criteria for dividing the EAC's assets and liabilities, also included a provision for the future re-establishment of the Community. ${ }^{78}$

\subsection{The Re-establishment of the EAC}

Steps were taken to reestablish the Community at two summits of the head of states held in 1993 and 1997. In 1993, a Permanent Tripartite Commission for Cooperation was set up to oversee the drafting of a treaty for the establishment of the EAC, and in November 1999, the Treaty for the reestablishment of the East African Community was signed by the heads of state of Kenya, Uganda and Tanzania. The Treaty entered into force on 7 th July 2000. Two new members, Rwanda and Burundi, acceded to the Community in 2007 and the Republic of South Sudan in 2016, bringing its membership to six. The newlook EAC therefore constitutes a larger bloc than its defunct predecessor and with a combined population of more than 143.5 million people, land area of 1.82 million square kilometers, and a combined Gross Domestic Product of $\$ 110.3$ billion, it constitutes a key driver of regional integration in the entire East African region. ${ }^{79}$

The EAC has already achieved some of its objectives; it has managed to establish a Customs Union (2005) and a Common Market (2010), and is in the process of establishing a Monetary Union. ${ }^{80}$ However, in light of its ambitious objectives, these achievements are rather modest. The Community aims ultimately to have a "prosperous, competitive, secure and politically united Eastern Africa" - a Political Federation of the East African States. ${ }^{81}$

\footnotetext{
78 Kiraso, supra note 70, at 4.

79 EAC Secretariat. (2012). East African Community Facts and Figures-2012. Arusha: East Africa Community.

8o $\quad$ EAC, supra note 65 . See further chapters 9, 10, and 13 on these developments.

81 EAC, supra note 68.
} 
As stated in its founding Treaty, Article 5(1), the objective of the Community is to develop policies and programs aimed at "widening and deepening cooperation among Partner States in political, economic, social and cultural fields, research and technology, defense, security and legal and judicial affairs for mutual benefit". ${ }^{2}$

The EAC thus aims to provide the public goods which the Member States cannot individually provide. As Reith and Boltz rightly observe, few of the many African regional blocs have set their sights so high. ${ }^{83}$ Even the more established organizations like COMESA, SADC and ECOWAS do not have a provision for political union in their founding treaties. By its integration process, and objectives, the new EAC typifies the regional blocs that have been spawned by the new wave of regionalism. It takes for its model the EU, and has adopted the EU's institutional framework-it is highly institutionalized. The new EAC also aims at far deeper integration than envisioned by its predecessor. The EAC has also provided in the founding Treaty, for safeguards against the fatal mistakes that led to the collapse of its predecessor, including, a gradual approach to integration; decentralization of powers from the Summit to the Council of Ministers; provision for people-centered and private-sector driven integration; inclusion of civil society as key stakeholders; and, stringent withdrawal procedures. ${ }^{84}$

However, questions still linger over the viability of this renewed attempt at integration in the East African region. Analysts have warned that unless the leading decision-makers in the EAC temper their rhetoric with some measure of action, the current attempt may, like the previous EAC, flounder. Reith and Boltz have noted that the EAC "is strong on paper, but weak in the implementation of its decision", and risks losing the support of civil society and becoming "the scapegoat of national politics" ${ }^{85}$ Immediately after the collapse of the first integration project, Mugomba had warned that no attempt at integration would be successful until there was an ideological consensus among partner states, the acceptance of a common economic strategy, and a willingness to tackle the asymmetries of regional distribution of integration benefits and losses. ${ }^{86}$ While these factors no longer constitute a real threat to integration, the project nevertheless faces other, even greater challenges.

\footnotetext{
$82 \quad$ EAC, supra note 68.

83 Reith \& Boltz, supra note 70, at 91.

84 Kiraso, supra note 70, at 4.

85 Reith \& Boltz, supra note 70, at 91.

86 Mugomba, supra note 76 .
} 
There are many challenges to be overcome to realize the integration to which the EAC aspires. The AfDB Strategy Paper on Regional Integration in the Eastern African Region lists four key challenges to successful regional integration, which are also true with regard to the EAC: weak institutional and human capacity of the RECs and national implementation units; poor performance of regional organizations which impedes their capacity to deliver expected benefits of integration; limited capacity to mobilize the participation of private sector actors in the structures and processes of integration, and insecurity and cross-border conflicts. ${ }^{87}$

The key challenge faced by the EAC is its ambitious nature weighed against its capacity. The EAC has adopted a tight integration plan that is scheduled to progress through the stages of integration "at a gallop"-with the customs union, the common market, monetary union, and the political federation all being achieved within set time frames. However, as the EU integration (which the EAC seeks to emulate) has shown, regional integration is a complex process that requires much time, and serious resources. The EAC's ambitious goals are inconsistent with the reality of its capacity, and the capacity of its Member States to achieve them. According to the AfDB Strategy Paper, the regional organizations in the East African region, including the EAC lack the adequate capacity and resources to plan, coordinate, and monitor the processes required to further the integration. ${ }^{88}$ For instance, it has no capacity to design complicated corridor investment projects, or for monitoring and evaluation mechanisms for the integration processes. ${ }^{89}$ The process of integration is further compounded by the reluctance of Member States of the organizations to cede requisite competences to regional bodies, which has meant that regional institutions have little power to make decisions that would enhance integration. The AfDB Strategy Paper also cites lack of convergence of attitudes towards regional integration as one of the challenges with which the Community is confronted. ${ }^{90}$ Together with the reluctance of the governments to cede sufficient authority to the regional institutions, and to enact legislation and regulations necessary to guide the integration process, the regional concerns and priorities are often also not really reflected in the national policies - the governments simply do not accord the regional integration project due regard.

87 African Development Bank, supra note 45, at vii.

88 African Development Bank, supra note 45, at vii.

89 African Development Bank, supra note 45, at vii.

9o African Development Bank, supra note 45, at 13. 
Furthermore, due to the reluctance of states to cede power to supranational bodies, the EAC is characterized by an excessive state monopoly over decisionmaking processes and institutions which in turn poses a serious challenge to successful integration. The EAC defines itself as an intergovernmental organization, and even though it has made provisions for the inclusion of other actors in its decision-making process, the monopoly of the decision-making process still rests with the governments of the states, leaving non-state actors and the civil society locked out of the integration process.

Moreover, effective and deeper integration in the EAC is greatly inhibited by the insecurity and political instability in the region. The AfDB Strategy Paper acknowledges that apart from offering the Member States the opportunity to achieve "better connectivity and enhance prosperity by collectively investing in growth and development to fight poverty, the EAC could also be a tool for resolving the many conflicts that have ravaged the East African region".91 Each of the five Member States, with the exception of Tanzania, has experienced at least one conflict—ethnic or civil—in the last two decades and each of the states is neighbored by at least one country experiencing one conflict or another. Security is indeed a "Public Good" that the nation-states have not been able to provide individually, and for which they need collectivity to provide. The AfDB Strategy Paper points out that the rampant political conflicts in the region constitute, a "regional public "bad" that frightens investors, inhibits development and stifles economic growth", and consumes resources that are badly needed for productive activities. ${ }^{92}$ Thus, it is underlined that the resolution of conflicts and the maintenance of peace and security constitute essential conditions for successful regional integration in the East African region. East African Region

Lamenting Africa's moral crisis at the turn of the twenty first century, the Ghanaian Philosopher, Kwame Gyekye remarked:

Confronted with a deep and resilient development crisis, with frequent military disruptions of the democratic political process resulting, inevitably, in political instability, uncertainty, and confusion, and with a poor demonstration of political morality resulting in pervasive and rampant

91 African Development Bank, supra note 45, at 16.

92 African Development Bank, supra note 45, at 16. 
political corruption[,] ... African life on the eve of the twenty-first century is not only confused but at a low ebb. ${ }^{93}$

The catalogue of the failures of the post-colonial African state is inexhaustible. Africa's fifty years of experiment with the Westphalian nation-state has been anything but successful. The African state has also, in the last few decades, had to contend with the phenomenon of globalization - the combination of the international forces, political actors and multinational organizationswhich, analysts argue, threaten its very existence. It is against the acknowledgement of the limitations and failures of the state, on the one hand, and the threat of globalization, on the other, that the debate on the new wave of regionalism in Africa has been carried out. The question has been whether the maddening rush by Africa for the formation of regional blocs in the recent years-most African states have overlapping membership in many regional organizations - is itself a concession of the limitations of the states in the light of the challenges with which the continent is confronted, and whether indeed regionalism constitutes the continent's best response to the failures of the state and to the threats posed by globalization.

This section has analysed the EAC in the context of the resurgence of regionalism across the globe in the last few decades and has probed the claim that new regionalism is the world's, and indeed Africa's, response to the decline and failure of the nation-state, and the threat of globalization.

93 Gyekye, K. (1997). Tradition and Modernity: Philosophical Reflections on the African Experience. New York: Oxford University Press. 